\section{地域ごとの津波避難計画策定に 関する事例紹介}

\title{
A CASE STUDY ON DRAWING UP A PLAN FOR EVACUATION IN TSUNAMI AT COMMUNITY LEVEL
}

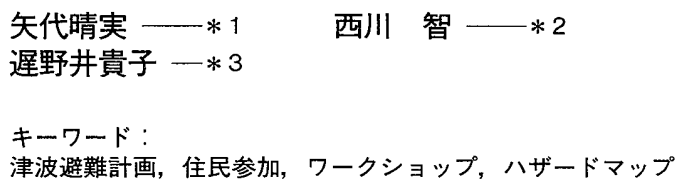

Keywords :

Plan for evacuation in tsunami, Public involvement, Workshop, Hazard map

\author{
Harumi YASHIRO $-* 1$ \\ Takako CHINOI $-* 3$ \\ Satoru NISHIKAWA —* 2
}

Tsunami has claimed many lives. There should be some ways of reducing the damage to human lives, which were caused by tsunami. At first, by analyzing the results of the questionnaire survey, it is recongnized that one of the issues is the lack of human resources, knowledge, and public involvement. The key is "Information Sharing" among the citizen, local government, and intellectual. To verify this, we did some case studies. We made each role clear. The practical evacuation plans had been made by holding the regional workshops, which were cooperated with citizen, local government, and intellectual. However, these plans are not final version because the plans should be revised regularly by conducting drills, and so on.

\section{1. はじめに}

過去に我が国では、多くの津波被害が発生している。津波対策と して防潮提、水門、陸閘の等の防災施設、防災行政無線等の設備が 進む一方で、津波浸水予測図の作成、避難対象地域の指定、避難場 所や避難経路の指定、避難勧告等の情報伝達等を含めた津波避難計 画を定めた市町村は少なく、ソフト面における津波避難対策を充実 する必要がある。

本研究では、海岸部を持つ都道府県、市町村すべてを対象とする アンケート調査を実施し、ソフト面における津波対策の問題点を明 らかにし、アンケートで問題になった事項を解決するために、モデ ル自治体を選定し、県による「指針作成」から、住民参加・参画に よる「地域ごとの津波避難計画」策定までを実践し、避難計画にお ける課題、課題解決策等の抽出を行った.

\section{2. アンケート調査結果と分析}

2.1 調査概要

津波避難計画策定の推進方策について検討を行うため、平成 13 年 8 月に、海岸部を持つ都道府県、市町村すべてを対象とする「津波対 策実施状況アンケート」調査を実施した ${ }^{1)}$. 回収率は表 1 に示すと おりである.

津波防災対策の実施状況についてハード面とソフト面に分けて実 施済夕の対策、今後の対策の実施予定等について調査を行った.

表 1 アンケート送付数、回収率

\begin{tabular}{|c|r|r|}
\hline & 都道府県 & 市町村 \\
\hline 送付数 & 39 & 1,022 \\
\hline 回収数 & 39 & 863 \\
\hline 回収率 & $100.0 \%$ & $84.4 \%$ \\
\hline
\end{tabular}

*1 東京海上火災保険侏（前アジア防災センター） 工博

(厂100-0005 東京都千代田区丸の内1-2-1 東京海上ビル新館 6 F)

*2 アジア防災センター 所長

*3 アジア防災セン夕-.. 研究員
ハード面において都道府県で実施済みが一番多い対策は潮位・津 波観測機器の設置である。今後更に充実させたい対策としては而震 岸壁整備、防波堤、防潮堤、水門整備などがあげられている. 市町 村においては、実施済从が一番多い対策は防波堤、防潮堤の整備で ある。今後更に充実させたい対策としては河川堤防の整備などがあ げられている.

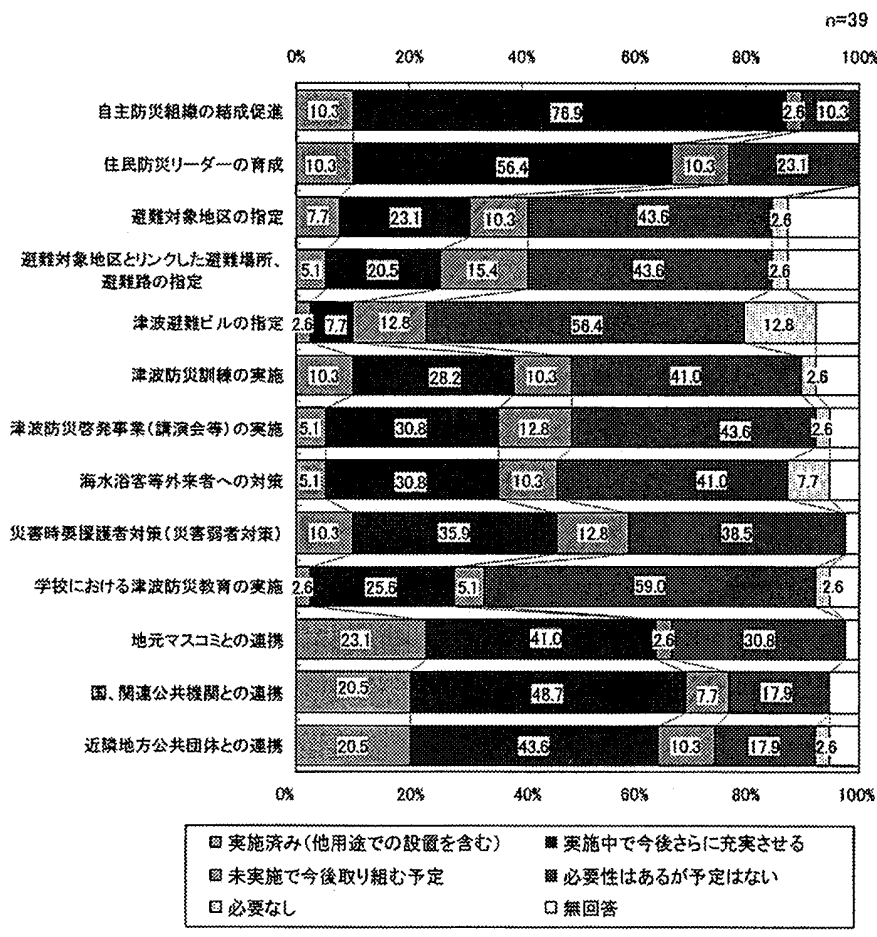

図 1 都道府県におけるソフト面の対策の実施状况 


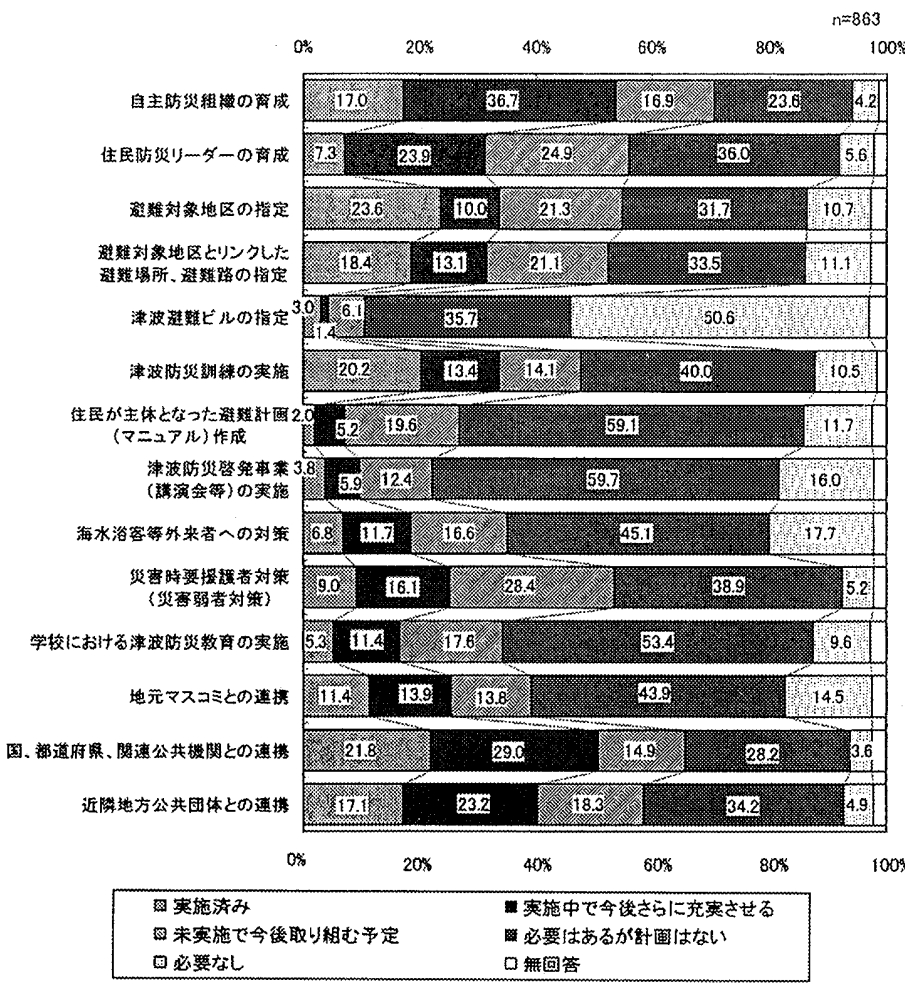

図 2 市町村におけるソフト面の対策の害施状況

\section{2ソフト面の対策}

ソフト面では、特に津波から敏速な避難が必要な地域での情報面 を含めた総合的な整備をしていくことが必要になる.

ソフト面について都道府県と市町村がおこなっている対策につい てのアンケート調査結果を図 1 、図 2 に示す.

「津波防災訓練の実施」、「避難計画の作成」、「避難対象地区 の指定」は、「必要はあるが計画がない」との回答が多かった。そ の対策が進まない理由について以下に考察する.

\section{(1) 津波避難訓練について}

都道府県、市町村共に「津波防災訓練の実施」は「必要はあるが 計画がない」との回答が多かった。実際に行われている訓練から課 題を抽出する.

津波避難訓練は、都道府県では毎年実施しているが 4 自治体、毎 年ではないが実施しているが 8 自治体、あわせて 12 自治体（約 31\%）であり実施率が低い，同様に、市町村は、毎年実施している のは、162 自治体（約 19\%)，毎年ではないが実施しているは、110 自治体（約 13\%）、あわせて 272 自治体（約 32\%）であり、やはり実 施率が低い．また、訓練参加者をみると、観光客等外来者の参加割 合が低く、津波避蜼訓練の実施の推進及び観光客等の外来者の参加 を得た訓練の実施が望まれる。訓練項目としては、避難場所への 避難、情報伝達、職員参集訓練などを主に実施しており、約 3 割未 満の自治体で、潮位観測、水門閉鎖などの訓練を実施している. 訓 練参加団体としては、消防本部、警察、消防団の参加は高いものの、 海上保安庁、漁協、ライフライン企業等の参加が低く、今後、多く の関係機関の参加が望まれる.

津波訓練の課題として、訓練のマンネリ化などによる参加者の減 少や、なかなか観光客が参加してくれないといった問題が多くあげら れていた. マンネリ化をさけ、観光客が参加しやすいイベント型の 訓練といつた、楽しく、更に実践的な知識等の提供を企画・運営し
ていくことが大切である.

23 避難対象地区、避難場所·経路の設定、避難計画の作成

津波避難対象地域を設定している市町村は 216 自治体（約 25\%） であり、根拠は、「浸水予測図による」は、90 自治体（約 42\%）、 「過去の津波被害による」は、68自治体（約 32\%）であった。

津波避難場所を指定している市町村は 411 自治体（約 48\%）で、 指定方法は「市町村が指定している」が 378 自治体（約 92\%）とな っている.

津波避難路を指定している市町村は 93 自治体（約 11\%）で、指定 方法は、「市町村が指定している」が 77 自治体 (約 83\%) で、「住 民が指定している」市町村は、15 自治体（;約 16\%）になっている. 指定した避難路に標識（看板）を設置している市町村は 53 団体（約 57\%) で、街路灯や夜光㙦料などを用いて液間避難に対応している市 町村は67 自治体（約 72\%）ある.

避難路を指定しない理由は、避難対象地区を設定しない理由と同 様の理由が多いが、避難場所へ到達する通路が複数あつて避難路を 定められないため（252 自治体;約 31\%）という理由も見られるが、 地域の避難路等を市町村が単独で決めることは困難であるためであ る. それは、地域の特性を熟知している住民が、具体的な避難計画 を決めなければ、津波が起きたときに逃る計画を立てることが難し いからである. 現状では「避難地区ごとの避難計画策定マニュア ル」を作成している市町村は 21 自治体 (約 2\%) で、ほとんどの団 体で未作成となつている.

\section{4 海水浴客 等外来者への対策}

釣り客、海水浴客、観光客等に対する避難対策としては、避難場 所標識の設置や避難に関するアナウンスの実施等を行つている都道 府県が数団体あるものの、特別な対応は実施していないという回答 が過半数を占めている.

\section{3. モデル自治体による津波避難計画の作成}

アンケートにより、都道府県による指針策定、それに基づく市町 村による避難計画、さらに地域住民参加・参画による「地域ごとの 津波避難計画」策定といつた課題か油出された.

本報告では、筆者らが平成 13 年度総務省消防庁からの委託により 作成した「津波対策推進マニュアル指針」実施にあたって、アンケ ートで問題になった事項を解決するために、モデル自治体を選定し、 マニュアルに沿って、県による「指針作成」、住民参加・参画によ る「地域ごとの津波避難計画」策定までを実践した.

実施内容は、以下のとおりである.

(1) 県、市町村関係各課之学識経験者による検討会開催.

(2) 上記検討会に基づく県による指針の作成.

(3) 県主催の、県内の海岸線を有する市町村に対する、指針の説明 会開催. 学識経験者により津波に関する知識やワークショップ の手法についての講演や、避難計画策定作成にあたってのサポ 一ト.

(4) 市町村は、県の津波浸水予測図や津波到達予想時間を反映し、 地域の実情に合った津波避難計画の作成.

(5) 地域住民が参加するワークショップの開催.

このような過程を経て、地域ごとの津波避難計画を作成した. 
モデル対象地域としては三重県尾鵇市、和歌山県湯浅町、広川町、 太地町、高知県高知市で行った。

\section{4. 津波対策推進マニュアル}

「津波対策推進マニュアル（指針）」の概要は以下の通りである. マニュアルは、津波避難対象地域、避難場所および避難路の指定、

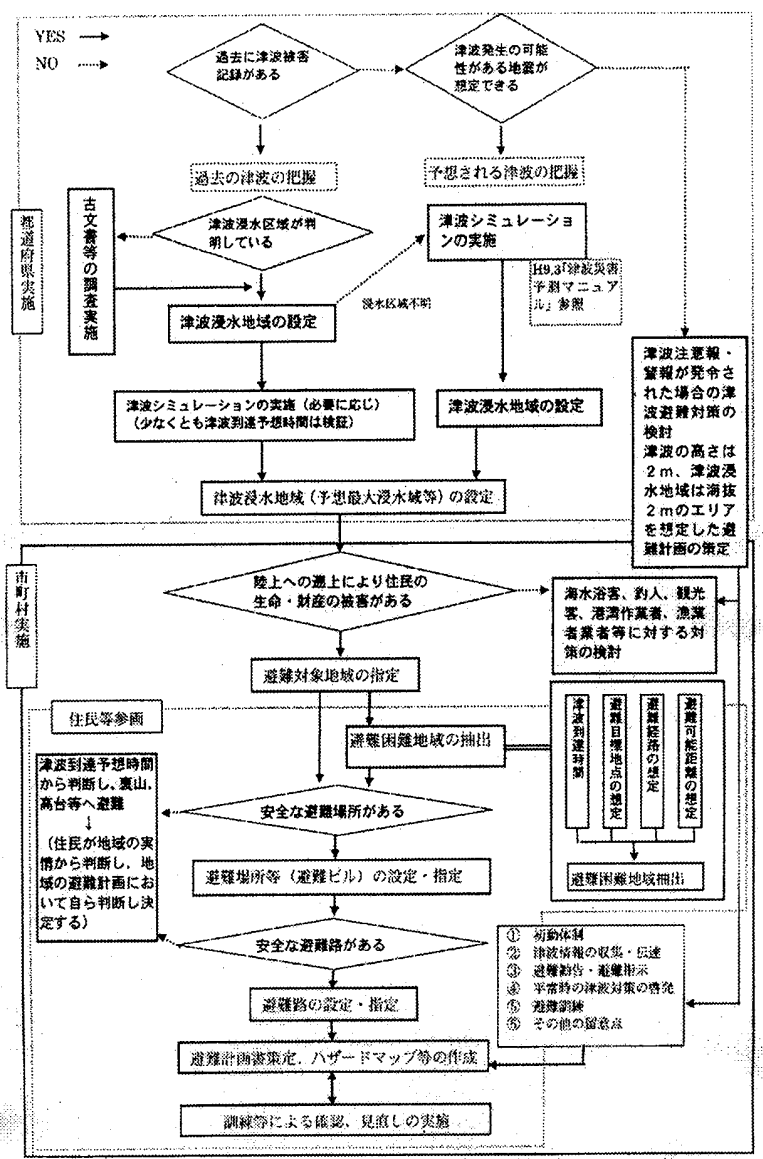

図 3 津波避難計画策定のフロー図 ${ }^{2)}$

津波予報等の情報収集・伝達の手順、避難勧告や支持の発令等を定 めた津波避難計画策定、津波防災意識啓発、避難訓練実施等、ソフ 卜面の津波対策を充実するために、津波避難計画策定等にあたり、 留意すべき事項について検討し、実施すべき事項を「地域ごとの津 波避難計画策定マニュアル」としてまとめたものである.

図3に津波避難計画策定のフロ一図を示す.

そのフローでは、はじめに 県、市町村等の、計画策定にあたり 果たすべき役割を定めた。それは、市町村が策定する計画への指針 策定、市町村に対する計画策定の支援、そして津波浸水予測図の作 成及び公表とした.

県は、市町村全体の計画策定（避難対象地域、避難場所、避難路 等の指定及び公表）と住民参画による地域ごとの津波避難計画の策 定の支援をすることとした.

そして住民は地域ごとの津波避難計画の策定（避難目標地点、避 難経路等の設定）を、果たすべきとした.

都道府県は市町村への避難計画策定指針作成にあたり、避難計画 を要する地域は、海岸線等（津波の遡上が予想される河川の流域等

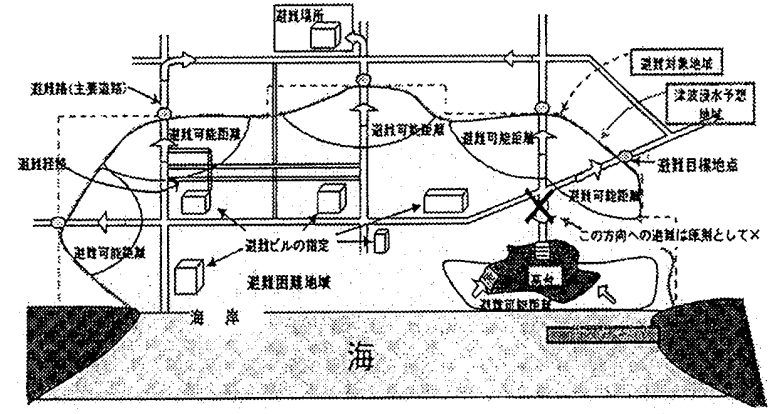

図4 津波避難計画概念図 ${ }^{2)}$

も含む）を有する全ての市町村とした．この指針で定めた津波避難 計画は、津波発生直後から津波が終息するまでの概数数時間〜十数 時間の間を対象としている. 津波浸水予測図、避難対象地域、初動 体制、情報の収集や伝達、避難訓練等についての内容が示されてい る。津波避難計画の概念を図4に示す．

\section{5. 和歌山県の事例}

筆者らがモデルケースで行なった和歌山県での実施例を以下に述 ベる。

\section{1 既往の対策}

和歌山県では、過去に東南海・南海地震による津波を想定し、津 波対策を行ってきた. 平成 8 年に浸水予測図、平成 13 年には「津波 避難計画指導マ二ュアル」を作成、平成 14 年に「和歌山地震対策協 議会、津波対策部会」が発足した. 和歌山県では住民参加による避 難計画を推進するために、図上訓練、ハザードマップの作成等を行 つている. また沿岸 21 市町村で津波避難訓練を実施している. 5.2 「市町村における津波避難計画策定指針」の策定

県総務部消防防災課、県土木部、湯浅町役場総務課、広川町役場 総務課、太地町役場総務課、学識経験者、総務省消防庁震災対策室 のメンバーで、検討会が 2 回開催され、地域防災計画と照らしなが ら、「市町村における津波避難計画策定の指針」を検討し、指針を 作成した. その後、沿岸市町村に、指針についての説明会を実施し た. 指針は、避難計画の目的、修正、そして基本的な考え方が記載 されている. 本計画の定める必要がある 11 事項として、総則、津波 浸水予想地域、避難対象地域、避難困難地域、避難場所や避難路等 の設定、初動体制、津波情報の収集や伝達、避難勧告・指示の発令 基準や伝達方法等、津波対策の教育・啓発、津波避難訓練の実施、 その他留意点、がある. 市町避難計画の作成基準には、上記の 11 項 目に加え、避難目標地点、避難経路等を加えた 16 項目の設定方法を 詳細に述べている，県による市町村の避難計画策定の指針を受けて、 各市町村は津波避難計画書を作成する.

53 市町村による「地域ごとの津波避難計画」の策定

モデル地域に選ばれた湯浅町、広川町、太地町が、それぞれ津波 避難計画書を策定した.

モデル地域の選定は、県が対象の市町村を選び、選定された各市 町が、それぞれのモデル地域を選出した．各地域では、地域の特徵 や防災対策の現状が確認された，モデル地区は、以下のように選ば れた.

湯浅町、広川町は湯浅・広湾に面しており、過去の南海地震津波 により大きな被害を受けた経緯がある.また、広川町は、「稲むら 
の火」のモデルである浜口梧陵が作った「広村堤防」があり、住民 の津波防災に対する関心が高い，なお、湯浅広湾口には、本県初の 津波防波堤が建設中である.

湯浅町の主要な港湾は、田村漁港、栖原漁港、湯浅広港である. その周辺地域住民に、特に津波への取組みを進めて欲しいことから、 この 3 箇所をモデル地域とした. 田村漁港及び栖原漁港については、 漁港周辺地域にこだわらず区全体を、また、湯浅広港については周 辺地域の 3 地区（港区、なぎ区、なぎ団地区）をモデル地域とした.

広川町は、地理的要件や、建築物の安全性、住民構成等を勘案し、 危険性が高い地域から取り組みをすすめていくこととした. 広川町 の天皇区は、高齢者の多い地域である. みどり区は、平成 9 年以降 に県内、県外から転居した人が多く、津波に対する十分な情報を持 たない人々が多いと推測された。これらの理由から、津波に対する 脆弱性の高い地域と考え、天皇区とみどり区をモデル地区とした.

太地町は、東南海・南海地震か溌生した場合、津波の到達予想時 間が 10 分以内と非常に早く、津波からの避難か涃難な地域であると 思われる. また、本県の急傾斜地崩壊対策事業（急傾斜地の法面を 切り取った際にできる土地を津波避難地に利用する事業）が実施さ れている. 太地町には、津波の際に避難が予測される太地地区、森 浦地区、那智勝浦町 (飛地) の夏山地区がある. さらに地理的・地 形的・人工的見地から、3 集落を 5 地区に分割した. 今回のワ一ク ショップでは、その中から東新地区、寄水地区、森浦地区を対象地 区に設定し、東新地区は、大東、小東、新屋敷、寄水地区は、寄子 路、水の浦、暖海、森浦地区を今回、モデル地域とした.

\section{4住民参加によるワークショップの開催}

ワークショップは以下の事項を主な目的として開催され、町が 策定した指針を基に、湯浅町、広川町、太地町は、それぞれ 2 回づ つワークショップを実施し、住民参画型の津波避難計画を策定した.

ワークショップの主な目的として、下記の 3 点をあげた.

(1)津波災害時、安全に避難できるための避難計画を、住民自ら策定 するため

(2)住民が津波避難計画作成を通じて学んだことを各地域に持ち帰り、 地域の自主防災リーダーとして、自らの地域「防災力」を向上させ ること

(3)過去の津波災害から学んだことを後世に伝えること

湯浅町、広川町では、2町合同で津波避難計画策定指針の説明、 避難計画作成の打合せが行われた. そして学識経験者、県、町の担 当者等が、現地調査を含むワークショップの詳細な打合せを行った. 太地町では、県による津波避難計画策定指針の説明、避難計画作成 の打合せが行われて、他に県、町と住民のリーダーとの事前打合せ でなされた. 各自の役割分担を表 2 にあげる.

\section{表2 ワークショップの役割分担表}

\begin{tabular}{|c|c|}
\hline & 役割 \\
\hline \multirow[t]{2}{*}{ 地域住民 } & (1)住民等に対してワークショップへの㝜加への㭔ひかけ \\
\hline & (2)地域ことの津波避難計画の策定 \\
\hline \multirow[t]{2}{*}{ 町総務課職置 } & (1)ワークショジプ喤加への住民呼ひがけ \\
\hline & 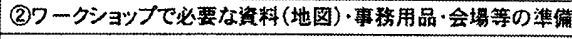 \\
\hline \multirow[t]{4}{*}{ 県消防助炎锞 } & (1)融䬣の派遗. \\
\hline & (2)津波·防災についての资料(津波浸水予澌図等)提供 \\
\hline & (3ワークシショップの運営補助 \\
\hline & 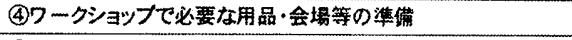 \\
\hline \multirow[t]{2}{*}{ 学識経駼者 } & 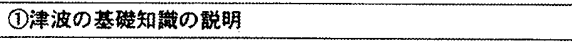 \\
\hline & (2)ワークショップの運営 \\
\hline
\end{tabular}

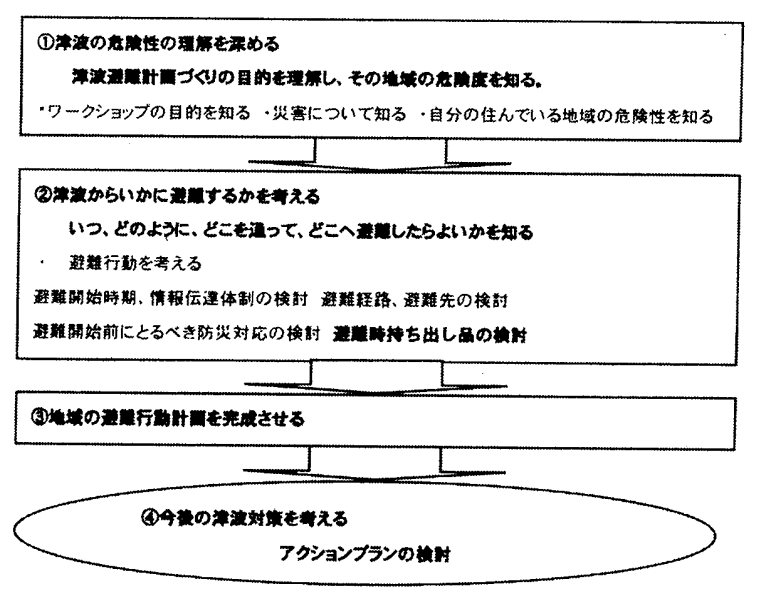

図5ワークショップの流れ

ワークショップの配布資料として、浸水予測地図、浸水実測図 （地震や津波の資料や過去の浸水域）之市町村が定めている避蜼対 象地域、避難場所、避蜼路等の資料（白地図（約 $1 / 1000 ） 、$ 住宅地 図を拡大したものなど）等を用意した.

ワークショップの流れは図5の通りである.

第 1 回のワークショップで、地域の津波の危険性を考元、避難計 画を浸水予測図に基づき、避難路や避難場所の検討した．まず、ワ 一クショップの目的について説明をし、その後、学識経験者がイラ ストや津波シミュレーションモデル等を用いて、災害の全体像、緊 急避難の必要性、メカニズム、そして恐ろしさについて具体的に説 明した，次に、地域の危険性についてまず、地域の危除性や安全な 地域といった情報を、住民がそれぞれの地域の地図に記入し、地域 の危険性を検討した．津波浸水予測図、津波の高さ、到達予想時間 等から、住民に自分の住んでいる地域のどの地区が津波により浸水 してしまう危険性が高いか、同時にどの地区が津波に対して安全か を検討した．震度分布図、木造建築物被害分布想定図、炎上出火件 数分布図といった様々な被害想定図も参考にして、地域の危険性を 検討した. 例えば、非木造建築物被害分布想定図等から地域の安全 な建物・場所等、震度分布図等から津波浸水予測地域て地震による 被害を多く受ける場所等を認識して避難計画に反映させた. 第 1 回 目の後、第 2 回ワークショップの資料として、避難場所等の問題点 のリストを作成した.

第 2 回ワークショップでは、地域の避難行動計画を完成させ、今 後の津波避難計画について検討した.

具体的には、避難開始時期や情報伝達体制、避難先、避蜼経路、 避難開始前にとるべき防災対応、避蜼時の持出品等の避難行動計画 について話合い、班ごとに発表した。ワークショップの最後の段階 において、住民自身によるアクションプランの提案（今後必要だと 思われる防災対策の提案）、提案されたアクションプランの整理 （地域における研修や訓練など啓発のための試み、津波避蜼マップ などの作成や配布、災害弱者への支援対策の検討などに分類）を行 った.

住民からは、研修・啓発、マップ配布、災害時要援護者 (災害弱 者）対策、地域内・家庭内での話合い等の充実、行政への要望、八 一ド施設の整備等に対する以下のような提案がなされた. 
(1)研修・啓発として、

・年 1 回防災の日（南海道地震のあった日）を設定し、地区集会等 を開催して津波について考えよう.

・各町内会での学習会、町でこのようなワークショップの開催する.

・各種団体 (婦人会、PTA、老人会) へ説明する.

• 天災は忘れた頃にやってくるので、時々繰り返し町内会て勉強す る機会を作る。

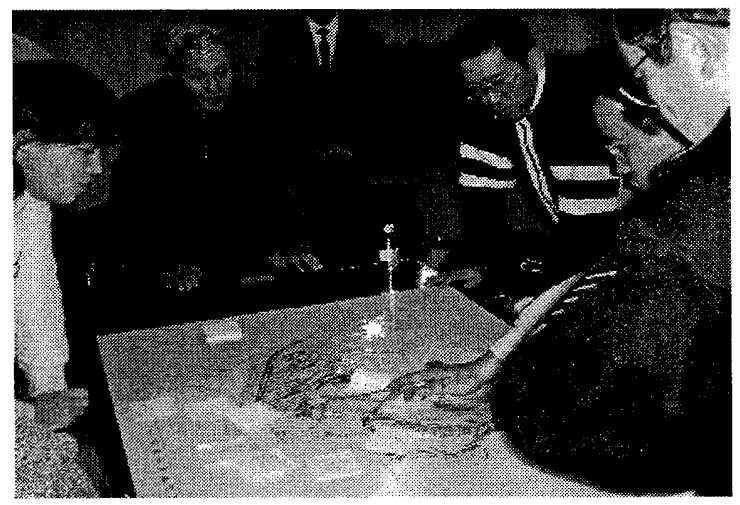

写真 1 津波避難地図の検討（広川町）

・このワークショップで学んだ事を資料にして全戸に配布する.

・区の総会でこのワークショップの冊子を説明し、区民の勉強会を

行い、今後の取り組みについて考える.

・津波体験者との交流したり、地域住民の避醮訓練実施する.

(2)マップ配布については、

・このワークショップで住民が作った避難マップを配布する.

・各地区のマップを冊子にし、住民に配布する際に、地区内で説明 会を開き、地図の内容理解を促する.

(3)災害時要援護者 (災害弱者) 対策として、

・老人や子供の多い家族などを町内会で日頃から調查し、津波避難 ができるようにしておく.

・老人や子供への津波避難浸透をはかるべく、彼らを対象にこのよ

うなワークショップを行う.

・高龄者・障害者の避難対策を検討し、避難訓練を実施する.

・独居老人、老夫婦の補助員をあらかじめ決めておく.

(4)地域内・家庭内での話し合い等の充実として、

・日頃から、津波などに備え貴重品などコンパクトにして準備して おくよう心がける。

・地区内の住民同士のネットワークを強化できるような防災教室を 開設する。

・各家庭内での話し合いをする．（檘難先．避難経路. 家庭内の災 害要援護者 (災害弱者) の避難方法等)

• 災害時のお互いの安全確認連絡網（携帯電話等）の確立する.

・短期避難に必要な物品をできる限りそろえ、方法を見出し、どの

ようにして実行可能力考える.

(5行政への要望には、

・町内放送による災害時の心得の PRする.

・長期避難用のテント又は簡易避覲施設を避難所の近くに確保して ほしい.

・避蜼道路、避難場所を住民と相談して整備してほしい.

(6)ハード施設の整備として、
・防波堤、避難場所を建設する.

太地町では、住民から提案された対策について、実行可能な対策か ぞうかについても、町職員と議論し、皆で今後どういった対策をと るべきか検討した。

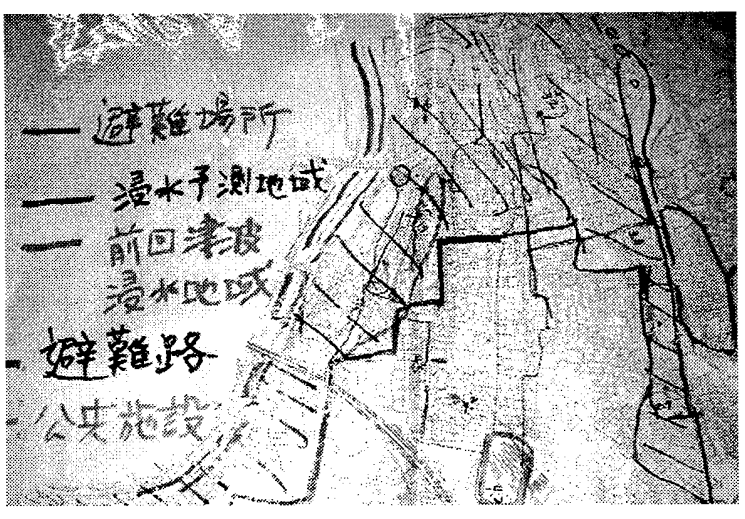

写真 2 住民作成地図例（湯浅町）

ワークショップで積み残された課題としては、避難困難地区や避難 目標地点が策定できなかった等が挙げられた. 今後避難場所の視察 を行うなど、継続的に津波対策を行っていく必要がある.

\section{5ワークショップの留意点}

ワークショップ開催に際して、行政としての留意点を (1)から(3)に、 住民としての留意点を(4)に示す.

\section{(1) ワークショップの準備}

\section{(1)住民参加の求め方}

地域の居住者だけでなく、旅館、ホテル、観光業者、地元企業関 係者、ボランティア、港湾・漁業関係者等、年齢層は若者からお年 寄りまで、幅広く呼びかける. 参加者の人数は、一地域約 30 人程度 とし、一地域を 3〜5 地区の班に分け、一地区あたり 6〜7 人の班編 成が望ましい。 ワークショップが機能するためには、地域住民の自 主的な参加を促すことがポイントとなる.

\section{(2)学識経験者への参加依頼}

地域の防災上の特徵だけでなく、社会環境や歷史的背景など地域 の実情を熟知した方が望ましい，地域の状況を踏まえつつ、専門的 な見地から適切な助言が得られる。

\section{(2) ワークショップの内容}

\section{(1)津波の恐布の認識}

津波発生の仕組从、予想される津波の高さ、浸水予想地域、津波 到達予想時間等をわかりやすい言葉で強烈に認識させる.

\section{(2)地震による地域の危険を認知}

津波による浸水予想地域や津波到達時間、津波の継続時間等を的 確に伝㫕、津波による被害 (危険性) 、避難が必要な時間等の周知 徹底に加え、地震の摇れによる被害についても配慮した避難計画を 策定しなければならない，特に、避難路や避難場所の設定において 重要となる.

\section{(3)今できることから取り組む}

防潮是や水門等の整備には長い年月がかかる。現時点で地域にお ける一番安全な避䧼路や避難場所を検討し、今後の対策を話し合う. 行政側は、すぐに実現可能な対策と、実現には長い期間を要する対 策等を可能なかぎり住民に伝える努力が求められる. 


\section{(4)津波避難のキャッチフレーズ}

住民に対して常日頃から津波辟難を促すキャッチフレーズ（補注

2）を設けることも意識啓発の上で有効な手段である.

(3) ワークショップの運営

\section{(1)かりやすい言葉を使う}

ワークショップの参加者が地域に戻って、地域住民へ津波避蜼計 画を語るため、わかりやすい表現を心がける.

\section{(2)住民の意見を却下しない}

住民の津波体験や言い伝え等の住民の声に耳を傾ける. また、現 在、指定している避難場所が地域住民にとっては不便であったり、 利用に不安を感じる場所であることもある. 行政の説明に対して地 域住民が納得しない場合は、住民の意見を十分に聞き、避難路や避 難場所、危険な簐所等を白地図に書き加えるなど、住民が主体とな つた避難計画を作成する．住民の考えや思いつきを無視せず、積極 的に取り入れる姿勢が必要である.

\section{(3)少数意見を大切に}

結論を早急に導き出そうとせず、少数意見にも耳を傾けるよう心 がける. 高龄者や子供などの災害時要援護者の視点に立った津波避 難についても、ワークショップの全参加者で考える.

\section{(4)タウンウォッチングは問題発見の場}

普段見慣れた風景であっても津波避難ということを念頭に周囲を 見渡すと、思わぬ発見がある. タウンウォッチングによる発見と問 題意識を、次回のワークショップに結び付けることが重要である.

\section{(4) ワークショップ誉加}

\section{(1)自分の身は自分で守る}

ワークショップは、市町村の津波避勒計画作成が目的ではなく、 自分や自分の家族、隣人皆が被害を回避する方法を考える場である。 防潮是や避難所の整備といったハード面の事業にばかり頼ろうとし ない.

\section{(2)思ったことは発言する}

ワークショップでは、疑問が生じたら何でも聞くよう心がける。 何が危険なのか、漁船の様子を見に行ってもよいのか、いつ避蜼し たらよいのか、何を持って避難したらよいのか、津波警報で避難し たときはいつまで避難していなけれればいけないのか等々、疑問に思 うことは他の住民も疑問に思っている.

\section{(3人を批判しない}

同じワークショップに参加していても、参加者全員が同じ考えと は限らない．参加者同士が、他人の意見を即座に批判したり否定す るのではなく、前向きな意見を述べよう.また、逆に他人の意見を 取り入れ自分の考えを発展させていくことが望ましい.

\section{(4)住民間の意思疎通の重要性}

ワークショップにおいては、住民同士で十分に話し合いを行い、 より多くの参加住民の声を計画に反映させることが大切である. 防 災対策の推進には、地域コミュニティの育成が鍵となる.

\section{(5課題之解決策を考える}

ワークショップでは、自分でできる解決策、地域住民の協力でで きる解決策、行政に頼む解決策、すぐできることから時間がかかる ことまで、様々な課題を挙げ、解決策をわかりやすく分類する，そ して、まず、自分でできることから実行してみる.

ワークショップ後、地域住民より、防災意識の高まりと共に、行
政に対する様々な提案や要望がなされるかもしれない。財政的制約 等、それら全ての要望に応えることは困難だが、住民の防災意識を 維持していくためにも、住民と行政が協働して少しずうでも継続し て津波対策を進めていくことが必要となる.

ただし、作成された津波避難計画が完成版ではない。避難訓練の 実施等を通じ、より良い計画に毎年改定していくこと必要である.

行政と地域住民が一体となった、継続的な取組みが不可欠である.

\section{6.まとめ}

本研究では、海岸部を持つ自治体を対象とするアンケートを実施し、 問題点抽出した。そして問題点解決のためのマニュアルを作成し、 そのマニュアルにおける避難計画策定において住民とのワークショ ップをモデル地区で央施した. これらを通じ、以下の結論を得た. (1)アンケート実施により津波に対する避蜼訓練は、多くの自治体で 行われていない事. また、津波の避難路の指定がほとんどされてい ない事等が明らかになった。

(2)津波対策推進マニュアル作成し、津波に対する避蜼路の指定等の 問題を解決するために、県による「指針作成」、市町村・住民によ る「地域ごとの津波避蜼計画」の方法・手法を策定し、県・市町村 等の自治体、住民の役割を明確にした.

(3津波避難に関する自治体・学識経験者、住民によるワークショッ プをモデル地区で実施し、安全に避難するための避蜼計画を住民自 ら策定する過程において、地域の危険度の把握、問題点の抽出等を 通じ地域の「防災力」を向上させることが可能になることを明らか にした.

\section{補注}

1ワークショップ終了後、住民からワークショップの開催要望がでたり、地域 によっては、自主的にタウン・ウォッチングを行い避蜼経路や避歏場所を確 認した地区もあった

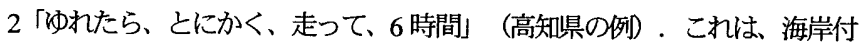
近で地震の摇れを感したら、とにかく素早く避蜼する。また、津波繰り返 し襲ってくるので、少なくとも 6時間は安全な場所に避蜼する、との意味.

\section{陆辞}

本報告は、総務省消防宁の委託により筆者らが施した平成 13 年度「津波

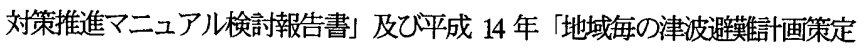
モデル事業事例報告書」の実施内容の一部を報告したものである。また、本 報告における检討会、ワークショップ等において、京都大学防災研究所 河 田教授、東北大学大学院工学研究科今村教授、富士常葉大学環境防災学部 重川教授、三重大学教盖学部 本田助教授、和歌山高等専門学校、池田助教 授に御指導、御助言を頂いたことに感㴬致します。

\section{参考文献}

1) アジア防災センター、津波凉策推進マニュアル検舒報告書、平成 14 年 3 月、総務省消防庁霞災対策室委託事業

2) アジア防災センター、地域ごとの津诐避蜼計画策定モデル事業事例報告、 平成 15 年 3 月、総務省消防宁震災対策室委託事業

[2003年10月20日原稿受理２004年 2 月23日採用決定］ 